\title{
Pengembangan Media PowerPoint IPA Untuk Siswa Kelas IV SD Negeri Samirono
}

\author{
Widya Wijayanti ${ }^{*}$, Stefanus Christian Relmasira² \\ 12 Program Studi Pendidikan Guru Sekolah Dasar, Fakultas Keguruan Ilmu Pendidikan Universitas Kristen \\ Satya Wacana
}

\begin{abstract}
Abstrak
Penelitian ini merupakan penelitian Research and Development yang menghasilkan media berupa media pembelajaran berbasis teknologi terutama media PowerPoint IPA untuk siswa kelas IV. Penelitian ini bertujuan untuk kebutuhan sekolah, meningkatkan ketertarikan dan menghasilkan media PowerPoint untuk

Keywords:

Pengembangan, uji coba, validasi, media, PowerPoint, teknologi peserta didik yang layak. Pengembangan media PowerPoint dilakukan dengan 3 langkah pokok yang harus dilakukan yaitu yang Pertama, studi pendahuluan untuk mengetahui kebutuhan Sekolah Dasar dan pentingnya media. Kedua, penyusunan draft produk memulai tahap pembuatan desain PowerPoint, validasi materi, validasi media. Ketiga, uji coba produk untuk siswa kelas IV. Hasil penelitian ini berupa media pembelajaran berbasis Teknologi terutama PowerPoint yang berisi materi pendidikan IPA Subtema 2 yang telah divalidasi oleh ahli media, ahli materi, dan dinyatakan layak. Media PowerPoint telah diuji cobakan kepada siswa Sekolah Dasar dan siswa mampu memahami materi IPA tentang Selalu Menghemat Energi. Pada tujuan Pengembangan Media PowerPoint IPA menggunakan model AADIE untuk mengetahuo seberapa tinggi validasi produk model oleh ahli. Valdasi materi pembelajaran oleh ahli materi diperoleh sebesar 75,5\% dengan kategori tinggi dan validasi media pembelajaran oleh ahli media diperoleh sebesar 46,25\% dengan kategori tinggi. Selain mengetahui seberapa tinggi validasi ahli juga untuk melihat apakah media PowerPoint dapat menarik siswa dalam pembelajaran menggunakan teknologi.
\end{abstract}

\section{PENDAHULUAN}

Menurut (Susanto, 2013), menjelaskan bahwa pada dasarnya pembelajaran adalah sebuah proses atau tindakan yang dirancang untuk memudahkan peserta didik dalam mengembangkan potensi yang dimiliki secara maksimal. Pada pembelajaran dikelas tidak semata-mata guru melaksanakan pembelajaran namun juga harus memiliki tanggungjawab yang dapat membantu peserta didik dalam mengkondisikan kelas, peserta didik, bagaimana mengaplikasikan materi pelajaran itu sendiri, dan media yang akan digunakan untuk pembelajaran itu sendiri sangat berpengaruh. Media pembelajaran juga memiliki peran penting dalam dunia pendidikan. Menurut (Sanjaya, 2010), media bukan hanya alat perantara seperti TV, radio, slide, bahkan cetakan, akan tetapi meliputi seseorang sebagai sumber belajar yang dikondisikan untuk memperoleh pengetahuan dan wawasan mengubah sikap seseorang serta menambah keterampilan. Media pembelajaran adalah salah satu media alternatif dalam meningkatkan hasil belajar siswa. Dalam setiap pengembagan produk tentunya akan ada kesulitan atau kendala terutama pada guru, kendala yang dialami guru dalam pembuatan dan penggunaan media pembelajaran PowerPoint adalah editing video agar sesuai kebutuhan PowerPoint, input Hyperlink, sarana prasarana yang tidak berfungsi dengan baik, pemilihan gambar dan animasi yang sesuai materi relative lama, menurut (Jannah, 2017)

\footnotetext{
* Corresponding author. 
Menurut (Maria Resti Andriani, 2016) pembelajaran menggunakan media PowerPoint ini dirancang untuk pembelajaran yang interaktif, dimana dalam media presentasi PowerPoint dirancang dan dilengkapi dengan alat pengontrol yang dapat dioperasikan oleh pengguna sehingga penggunaan dapat memilih apa yang dikehendaki untuk petunjuk penggunaan, materi, dan soal latihan. Perkembangan teknologi sangat penting dalam mendukung proses pembelajaran. Salah satu media pembelajaran adalah Microsoft PowerPoint. Menurut (Sanaky, 2013) menjelaskan bahwa media PowerPoint adalah program aplikasi presentasi yang merupakan salah satu program aplikasi dibawah Mircosoft Office Program komputer dan tampilan ke layar menggunakan bantuan LCD proyektor. Di Sekolah Dasar (SD) teknologi juga diperlukan karena akan menunjang kulitas sekolah itu sendiri. Secara garis besar kebutuhan SD akan media interaktif adanya perkembangan teknologi didunia pendidikan sehingga peserta didik dan guru dapat belajar dengan secara efisien, dapat juga meningkatkan hasil belajar siswa, dan meningkatkan mutu pada sekolah.

Pada mata pelajaran IPA memiliki fungsi yang dijelaskan dalam Sumaji (2006), antara lain: 1)Memberikan bekal pengetahuan dasar, baik untuk melanjutkan ke jenjang yang lebih tinggi maupun menerapkan di kehidupan sehari-hari, 2)Mengembangkan keterampilan, dalam memperoleh, mengembangkan konsep-konsep IPA, 3)Menanamkan sikap ilmiah dan melatih siswa memggunakan metode ilmiah, 4)Menyadarkan siswa akan alam dan segala seindahnya, 5)Memupuk daya kreatif dan inovatif siswa, 6)Memahami gagasan atau informasi baru dalam nidang IPTEK (Ilmu Pengetahuan dan Teknologi), 7)Mengembangkan minat siswa terhadap IPA. Dengan ini IPA bertujuan untuk memberikan pengalaman serta ilmu dengan cara menjelajahi dan memahami alam sekitar secara ilmiah. Dengan adanya mata pelajaran IPA siswa dapat belajar tentang dunia sains. Siswa juga dapat menerapkan kedalam kehidupan sehari-hari.

Berdasarkan wawancara dengan guru kelas IV SD Negeri Samirono dan obeservasi dengan peserta didik yang dilakukan untuk memperoleh informasi tentang penelitian yang akan dilakukan. Kebanyakkan metode yang digunakan dalam pembelajaran sampai sekarang adalah ceramah, tanya jawab, demonstrasi, dan problem solving. Guru cenderung menggunakan media pembelajaran yang nyata misal, jika sedang mempelajari tumbuhan guru membawa tanaman. Sedangkan media yang digunakan lebih kepada buku paket, buku pendamping, dan lingkungan. Alat atau media pembelajaran yang kurang lengkap menjadi salah satu kendala ketika dilakukannya proses belajar mengajar. Namun, membuat siswa menjadi berkembang dari hasil belajar siswa yang meningkat. Untuk pengenalan teknologi kepada siswa masih belum sepenuhnya dilakukan dipembelajaran. Pada kesimpulannya guru belum menggunakan teknologi atau media yang berhubungan dengan teknologi untuk proses belajar mengajar terutama dikelas IV.

\section{METODE PENELITIAN}

Dalam penelitian dan pengembangan memiliki langkah-langkah, seperti yang dikemukan oleh Sugiyono (2013), dengan langkah-langkah penelitian dan pengembangan antara lain yaitu: 1). Potensi masalah, 2). Pengumpulan data, 3). Desain produk, 4). Validasi desain, 5). Revisi desain, 6). Uji coba produk, 7). Revisi produk, 8). Uji coba pemakaian, 9). Revisi produk, dan 10). Produksi. Selain penggunaan pengembangan Research and Development (R\&D), penelitian juga menggunakan metode AADIE dimana ada 5 tahap, yaitu (1). Analysis (analisis), (2). Design (perancangan), (3). Development (pengembangan), (4). Implementation (implementasi), (5). Evaluation (evaluasi) menurut Endang Mulyatiningsih (2012). Subjek penelitian ini adalah siswa kelas IV SD Negeri Samirono yang berjumlah 30 siswa, jumlah siswa laki-laki 12 dan jumlah siswa perempuan 18 siswa. Penelitian ini dilakukan selama bulan Desember 2018 sampai Februari tahun 2019 di SD Negeri Samirono dan SD Wates 2 Getasan. Penelitian ini dilakukan dengan teknik pengumpulan data yang digunakan adalah Pre test dan Post test. Teknik ini digunakan untuk mengetahui ketertarikan siswa pada media pembelajaran yang berbasis teknologi terutama pada media PowerPoint. Teknik pengumpulan data yang digunakan adalah teknik Pre test dimana menggunakan angket sebelum dilakukannya Post test untuk mengetahui ketertarikan siswa pada media pembelajaran. sedangkan teknik pengumpulan data post test dilakukan menggunakan angket dan evaluasi soal sesuai materi untuk menganalisis data berupa hasil obeservasi guru dan siswa. Data yang diperoleh dalam penelitian ini berupa: 1). Data hasil obeservasi siswa, 2). Data hasil studi pendahuluan guru, 3). Data hasil Pre test dan Post test pada penelitian ini adalah ketuntasan siswa $60 \%$ dari jumlah seluruh siswa. 


\section{ANALISIS DAN PEMBAHASAN}

Dalam peningkatan kualitas belajar saat ini didukung adanya sarana dan prasarana sebagai penunjang. Menurut (Novetasari, 2013), keberhasilan pembelajaran sangat mempengaruhi kelengkapan sarana atau media yang digunakan sebab semakin bervariasi media yang digunakan pesan atau materi pembelajaran akan semakin optimal diterima peserta didik. Hal ini disebabkan variasi dan keragaman modalitas belajar siswa bisa terakomondasi dan media yang variatif dalam pembelajaran. selain untuk menunjang hasil belajar juga dapat memberikan pengalaman yang lebih efektif dari segi waktu dan metode yang digunakan. Pada tahap pemilihan media sangat mempengaruhi hasil belajar. Media Pembelajaran yang dibuat interaktif berbasis multimedia dapat meningkatkan minat belajar siswa, menurut (Rizki Arfiyani, 2015). Tidak hanya media yang digunakan namun strategi dalam penyampaian materi pada siswa diperlukan dengan begitu siswa akan termotivasi dan lebih meningkatkan hasil belajar. oleh sebab itu pendidik harus mempunyai strategi untuk meningkatkan minat dan hasil belajar peserta didik agar tidak bosan dalam mengikuti proses belajar mengajar, menurut (Dwy Unggul Wibowo, 2018)

Pengembangan Media Interaktif PowerPoint IPA Untuk Siswa Kelas IV SD Negeri Samirono sudah melaksanakan penggunaan Research and Development (R\&D) dan model ADDIE yang mana peneliti mengujikan media pembelajaran yang berbasis teknologi terutama PowerPoint, untuk mengetahui ketertarikan siswa pada materi dengan metode lain yang digunakan selain ceramah dan untuk mengukur kemampan guru dalam penggunaan media pembelajaran PowerPoint. Penelitian ini bertujuan untuk Pengembangan Media Interaktif PowerPoint IPA Untuk Siswa Kelas IV SD Negeri Samirono, dengan mengembangkan dan penggunaan metode Research and Development (R\&D) dapat diketahui adanya langkah-langkah dalam Pengembangan Media Interaktif PowerPoint untuk peserta didik di Sekolah Dasar (SD), untuk mengetahui kualitas produk pengembangan media ini, dan mengetahui kefektifan pembelajaran IPA dalam meningkatkan hasil belajar peserta didik. Hasil penelitian ini akan menyajikan proses Pengembangan Media Interaktif PowerPoint IPA Untuk Siswa Kelas IV dengan menggunakan metode Research and Development (R\&D).

Pada tahap awal peneliti mendesain sebuah media yang akan diujikan namun sebelum produk yang berupa media tersebut dapat dikembangkan maka harus divalidasi oleh ahli materi dan ahli media. Revisi produk awal berdasarkan masukan atau saran dari ahli media dan ahli materi yang kemudian diterapkan pada uji coba terbatas. 1 kali uji coba terbatas dilakukan pada siswa kelas IV SD Negeri Samirono berjumlah 18 dari 30 siswa. Berdasarkan data yang diperoleh sebelumnya bahwa ketertarikan siswa terhadap media interaktif berbasis teknologi terutama pada penggunaan PowerPoint. Kegiatan pembelajaran dilakukan oleh penulis sesuai dengan Rencana Pelaksanaan Pembelajaran (RPP) yang telah disetujui guru dan kepala sekolah. Dimulai dari kegiatan pendahuluan dengan mengawali berdoa dan menyampaikan tujuan pembelajaran yang akan dicapai siswa setelah melakukan proses pembelajaran. Selanjutnya guru meminta siswa mengamati energi disekitar lingkungan kelas/sekolah, kemuadian guru mengajukan pertanyaan bagaimana peranan listrik dan sinar matahari dalam kehidupan sehari-hari, apa saja contoh macam-macam sumber energi.

Penelitian ini bertujuan untuk mengembangkan media PowerPoint IPA, penelitian ini menggunakan langkah-langkah pengembangan AADIE yang terdiri atas 5 tahap, yaitu (1). Analysis (analisis), (2). Design (perancangan), (3). Development (pengembangan), (4). Implementation (implementasi), (5). Evaluation (evaluasi) menurut Endang Mulyatiningsih (2012). Untuk mengetahui kualitas produk media PowerPoint, mengetahui seberapa efektif, dan mengetahui seberapa menarik media berbasis teknologi terutama media PowerPoint untuk siswa.

Dalam melaksanakan penelitian ini peneliti pertama-tama melakukan observasi lapangan dengan mengobservasi guru ketika mengajar di kelas dengan metode ceramah. Berdasarkan hasil studi pendahuluan ada beberapa peserta didik yang kurang memahami materi dan cenderung tidak tertarik dengan materi. Guru hanya melaksanakan dengan menggunakan metode ceramah tanpa ada alat peraga atau media untuk menarik siswa dalam proses pembelajaran. Oleh sebab itu, perlu dirancangnya atau desain sebuah media yang berbasis teknologi terutama media PowerPoint untuk meningkatkan motivasi siswa dan menarik minta siswa dalam proses pembelajaran.

Tahap kedua yaitu, peneliti merancang desain media Powerpoint menggunakan metode AADIE yang dilengkapi dengan teks, gambar yang menarik, animasi yang sesuai dengan materi, video yang dapat menjelaskan lebih dalam tentang materi. Tahap ketiga, jika media PowerPoint sudah jadi peneliti melakukan uji validasi oleh ahli desain. Selain ahli desain, peneliti juga melakukan uji validasi materi pada ahli materi, yang selanjutnya direvisi sebelum dilakukan uji coba terbatas di SD Negeri Samirono. Berdasarkan revisi pada ahli media dan ahli materi media yang sudah direvisi dan direvisi sebagai contoh dibawah ini 


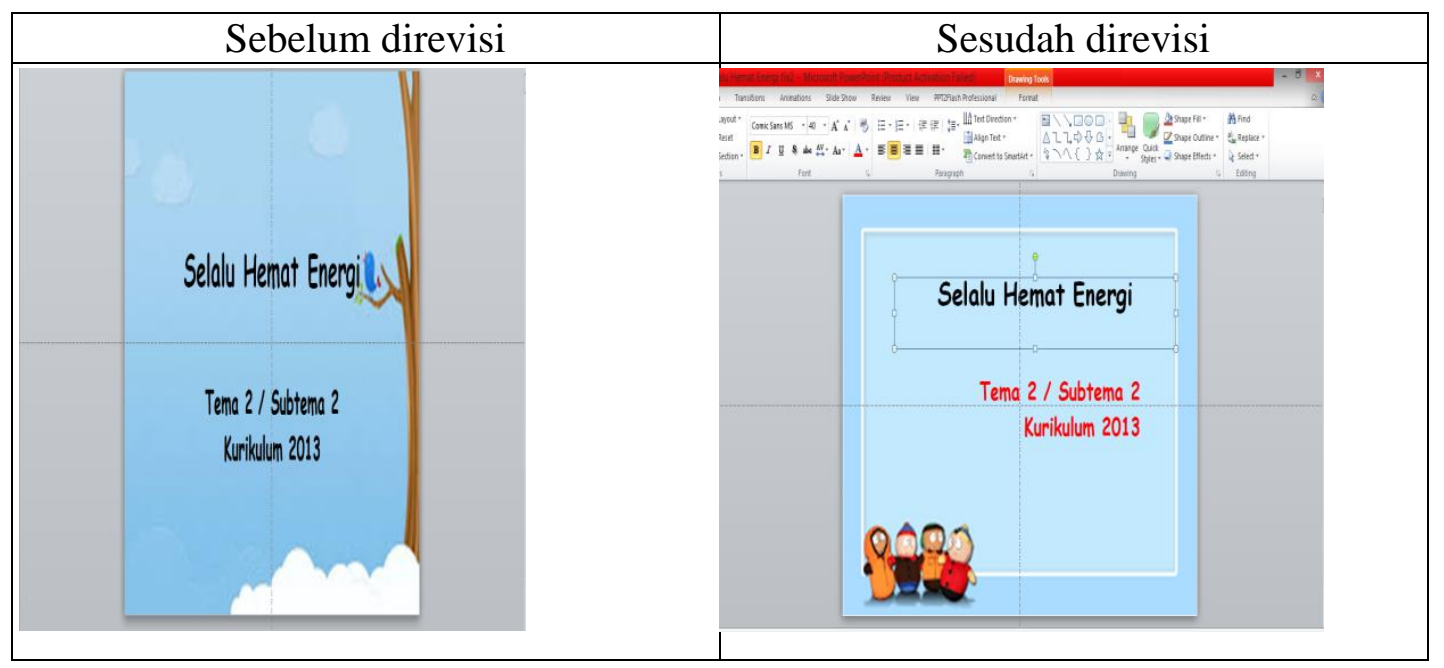

Gambar 1. Mengganti background

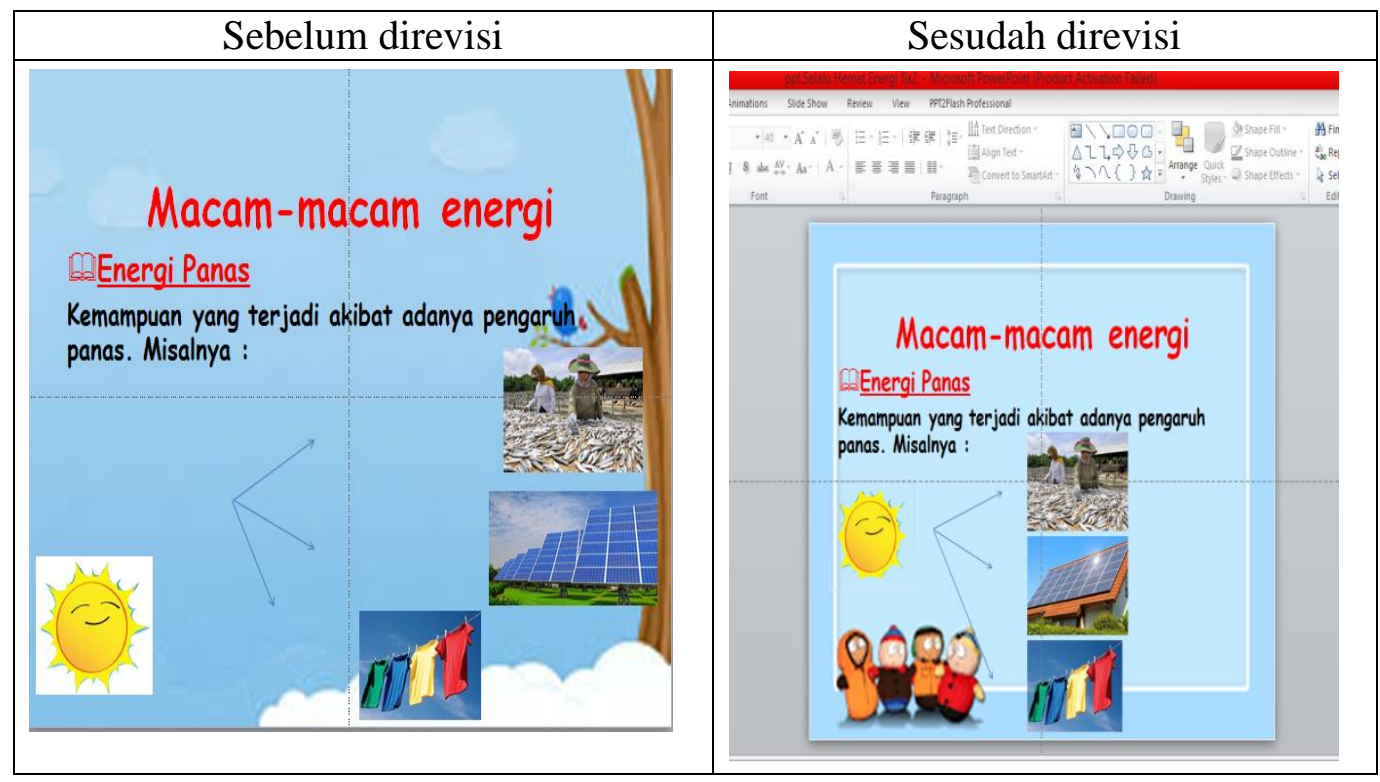

Gambar 2. Perubahan Warna

Setelah uji coba terbatas dilakukan, peneliti merevisi produk tersebut dan menandakan produk tersebut sudah final atau selesai. Pada tahap keempat, dengan pengembangan materi yang ada pada media PowerPoint membuat siswa lebih mudah memahami materi pelajaran, dan meningkatkan hasil belajar. Dengan begitu siswa dapat memperoleh pengetahuan lebih dalam, mengingat tematik menuntut siswa aktif dengan penggunaan tema yang disesuaikan dengan kehidupan nyata siswa. Selain itu dengan mengembangkan media PowerPoint menjadikan guru lebih mudah dalam menyampaikan materi kepada siswa dan lebih efetif dalam proses pembelajaran. Untuk tahap kelima yaitu evaluasi, perancangan media PowerPoint harus memastikan masalah yang relevan dengan program, misalnya pelatihan guru pada penggunaan media pembelajaran berbasis teknologi terutama pada PowerPoint, kemudian baru akan terlihat apakah tujuan yang diinginkan terpenuhi.

Tujuan Pengembangan Media PowerPoint IPA menggunakan model AADIE untuk mengetahuo seberapa tinggi validasi produk model oleh ahli. Valdasi materi pembelajaran oleh ahli materi diperoleh sebesar 75,5\% dengan kategori tinggi dan validasi media pembelajaran oleh ahli media diperoleh sebesar $46,25 \%$ dengan kategori tinggi. Selain mengetahui seberapa tinggi validasi ahli juga untuk melihat apakah media PowerPoint dapat menarik siswa dalam pembelajaran menggunakan teknologi. Pada dasarnya pengembangan media PowerPoint ini baik karena memenuhi standar model desain pembelajaran yang baik, dan mendapat respon posistif dari ahli, guru, maupun siswa. Sehingga sudah dapat digunakan oleh 
guru sebagai pedoman untuk mengembangkan media PowerPoint lainnya. Namun bila diperbanyak sebaiknya dilakukan uji coba luas dan uji coba keefektifan model.

Berdasarkan tiga penelitian terdahulu menunjukkan model pembelajaran tematik diterima oleh guru dan layak digunakan. Penelitian ini menyumbang pengetahuan dalam pengembangan media berbasis teknonologi terutama media PowerPoint memberikan pengetahuan dalam pentingnya media teknologi untuk menunjang proses pembelajaran. berdasarkan penelitian terdahulu juga mendukung penelitian ini terbukti bahwa model tematik integratif yang dikembangkan semuanya cocok dan layak digunakan dalam proses pembelajaran di kelas tinggi, sehingga dapat dikatakan media PowerPoint memang tepat diterapkan dalam pembelajaran di Sekolah Dasar.

Media pengembangan PowerPoint memiliki tujuan lain yang dapat dijadikan pedoman atau contoh untuk gurru dalam merancang dan mengembangkan pemebalajaran Tematik yang digunakan guru untuk proses pembelajaran. pengembangan media PowerPoint dilengkapi dengan gambar, teks, dan video yang menarik siswa dalam belajar. Yang dapat mendukung guru sebagai media pembelajaran dikelas. Berdasarkan pemaparan model media pembelajaran yang baik dapat disimpulkan bahwa media PowerPoint memenuhi standar dan layak digunakan dalam pelaksanaan proses pembelajaran di Sekolah Dasar.

Jika dideskripsi menjadi persentase data sebelum dan sesudah menggunaka media PowerPoint yang dirangkum pada tabel 4.7 dibawah ini. penentuan jumlah kelas menggunakan rumus Struges (Sugiyono, 2013) yaitu $\mathrm{K}=1+3,3 \log \mathrm{n}$. K adalah kelas dan $\mathrm{n}$ adalah banyaknya data/siswa. Melalui rumus dapat diperoleh;

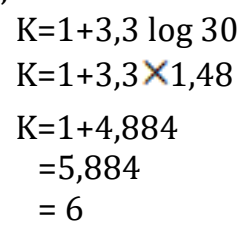

Diketahui bahwa skor sebelum dan sesudah dari 30 siswa SD Negeri Samirono memperoleh 51-56 terdapat 7 siswa dengan persentase 23\%, antara 57-61 terdapat 6 siswa dengan persentase $20,00 \%$, antara 62-67 terdapat 8 siswa dengan persentase 26,70\%, antara 68-73 terdapat 6 siswa dengan persentase $20 \%$, antara 74-79 terdapat 2 siswa dengan persentase 6,70\%, antara 80-85 terdapat 1 siswa dengan persentase $3,30 \%$. Jika dikembangkan dengan gambar dalam bentuk diagram dapat dilihat pada gambar 3 berikut ini.

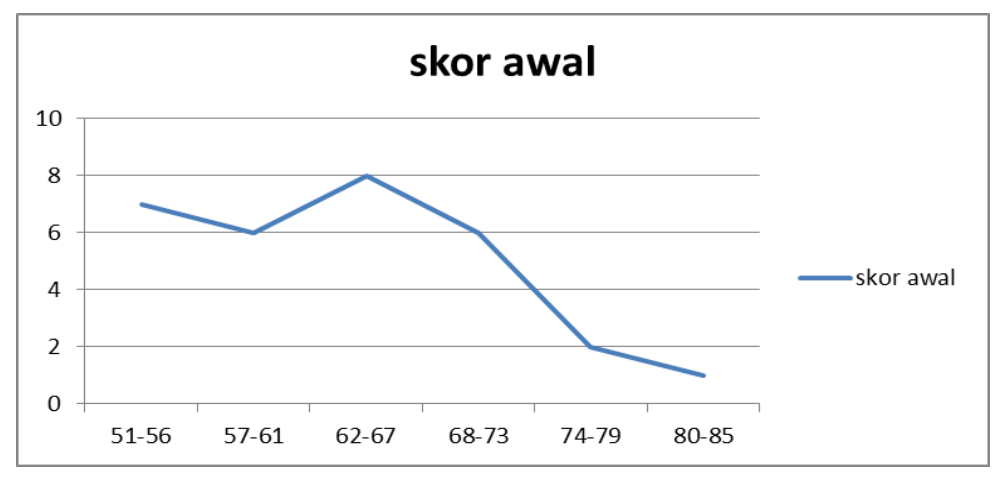

Gambar 3. Diagram Skor Awal Siswa

Setelah dilakukan uji coba dengan menggunakan media PowerPoint ketertarikan siswa pada media berbasis teknologi skor antara 86-89 terdapat 6 siswa dengan persentase 20\%, antara 90-93 terdapat 6 siswa dengan persentase $20 \%$, antara $94-97$ terdapat 7 siswa dengan persentase $23,30 \%$, antara $98-101$ terdapat 8 siswa dengan pesentase $26,70 \%$, antara 102-105 terdapat 2 siswa dengan persentase $6,70 \%$, antara 106-109 terdapat 1 siswa dengan persentase 3,30\%. Jika dikembangkan dengan gambar dalam bentuk diagram dapat dilihat pada gambar 4 berikut ini. 


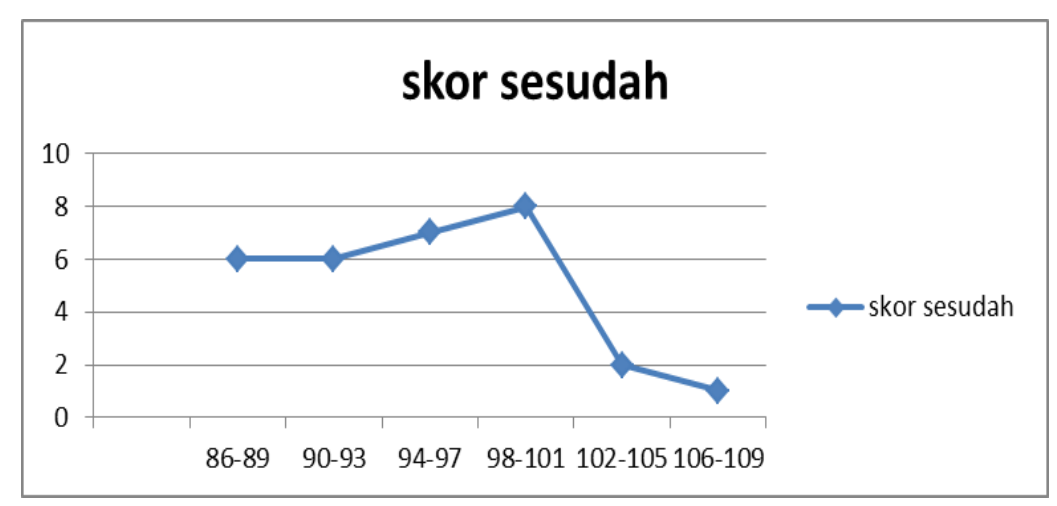

Gambar 4. Diagram Skor Akhir Siswa

Berdasarkan observasi dan refleksi tindakan yang telah dilakukan, pelaksanaan tindakan pembelajaran pada pelajaran IPA dengan menggunakan media PowerPoint telah berjalan sesuai dengan yang diaharapkan. Pengembangan Media PowerPoint juga terbukti meningkatkan tertarikan siswa kelas IV SD Negeri Samirono pada media pembelajaran berbasis teknologi.

Hasil penelitian ini sejalan dengan penelitian yang dilakukan oleh (Prasetyo , 2012), (Indriyanti, 2017), (Nurlatifah, 2013), (Mahnun, 2012), (Anik Ghufron, 2015), (Drs.Ahmad Syarifuddin, M.Pd.I, 2015) yang membuktikan bahwa Pengembangan Media Interaktif PowerPoint IPA Kelas IV. Penelitian ini menyatakan bahwa dengan media pembelajaran berbasis teknologi terutama PowerPoint dapat menarik siswa dalam proses pembelajaran.

\section{KESIMPULAN}

Berdasarkan hasil penelitian dan pembahasan dapat simpulkan bahwa pengembangan dan penggunaan media berbasis teknologi terutama media PowerPoint dapat meningkatkan ketertarikan siswa pada media pembelajaran bagi siswa kelas IV SD Negeri Samirono. Peningkatan keterarikan siswa pada media PowerPoint dapat dilihat dari pengisian angket sebelum dan sesudah uji coba terbatas. Pada pengisian angket menunjukkan adanya peningkatan ketertarikan serta dengan bukti adanya hasil belajar yang baik, dan bukti dengan ketepatan siswa dalam menjawab soal yang diberikan tanpa guru harus menjelaskan materi secara mendalam pada materi yang terkait.

Berdasarkan penelitian yang sudah dilakukan, peneliti menyampaikan saran sebagai berikut: 1) Penelitian ini telah menunjukan bahawa media PowerPoint layak digunakan dalam proses pembelajaran, salah satunya adalah memancing ketertarikan siswa dalam belajar. untuk itu peneliti berharap agar guru mampu menggunakan media PowerPoint atau media lain untuk mengajar di dalam kelas maupun diluar kelas untuk memberikan pengalaman yang baik untuk siswa. 2). Media PowerPoint dapat membantu guru dalam menyampaikan pesan pembelajaran kepada siswa dengan baik dan efektif. Oleh sebab itu, diharapkan supaya pihak sekolah dapat mendukung proses pembelajaran dengan memfasilitasi guru dan siswa dengan media pembelajaran yang dibutuhkan terutama pada media teknologi. 3). Dapat dikembangkan menuju tahap uji coba luas, sehingga terlihat lebih akurat perbedaannya. Lakukan tahap uji coba sampai ke beberapa SD dengan menggunakan kelas kontrol dan ekperimen. Kembangkan lebih dari satu subtema untuk memperoleh hasil yang lebih baik dan akurat.

\section{DAFTAR PUSTAKA}

Anik Ghufron, N. (2015). Pengaruh Penggunaan Media PowerPoint Terhadap Minat dan Hasil Belajar IPA Siswa Kelas IV SD. Jurnal Inovasi Teknologi Pendidikan .

Drs.Ahmad Syarifuddin, M.Pd.I, I. (2015). Pengaruh Penerapan Media Slide PowerPoint Terhadap Hasil Belajar Siswa Kelas III Pada Mata Pelajaran IPADI Madrasah Ibtidaiyah 2 Palembang . Jurnal Raden Fatah.

Dwy Unggul Wibowo, K. (2018). Pengembangan Media Interaktif Kerangka Manusia Meggunakan Adobe Flash CS6 Untuk Kelas 5 SD . Jurnal Pigur, 20. 
Indriyanti, R. (2017). Pengembangan Media Pembelajaran PowerPoint Interaktif Materi Penyesuian Makhluk Hidup Terhadap Lingkungan Untuk Siswa Kelas V SD Negeri Depok 1.

Jannah, N. F. (2017). Evaluasi Media Pembelajaran PowerPoint Pada Kurikulum 2013 Oleh Guru Mata Pelajaran Di SMP Negeri 2 Kudus. Unnes, 67.

Mahnun, N. (2012). Media Pembelajaran. Kajian Terhadap Langkah-langkah Pemilihan Media dan Implementasinya Dalam Pembelajaran.

Maria Resti Andriani, W. (2016). Pengembangan Media Pembelajaran PowerPoint Interaktif Melalui Pendekatan Saintifik Untuk Pembelajaran Tematik Inegratif Siswa Kelas 2 SDN Bergas Kidul 03 Kabupaten Semarang. Scholaria, 144.

Novetasari, F. (2013). Upaya Peningkatan Hasil Belajar IPA melalui Penggunaan Media PowerPoint IPA di Kelas 4 SDN 1 Ampel. Repository.

Nurlatifah, A. (2013). PENGEMBANGAN MEDIA PEMBELAJARAN IPA BERBASIS MICROSOFT OFFICE POWER POINT INTERAKTIF PADA SISWA.

Prasetyo , S. (2012). Pengembangan Media Pembelajaran Menggunakan Microsoft PowerPoint 2007 Dalam Pembelajaran IPA Di SD/MI.

Rizki Arfiyani, M. (2015). Pengimplementasian Media Pembelajaran Berbasis Multimedia Interaktif Pada Mata Pelajaran Matematika Di Sekolah Dasar. ejournal.

Sanaky, H. (2013). Media Pembelajaran Interaktif-Inovatif. Yogyakarta: Kaukaba Dipantara.

Sanjaya, W. (2010). Perencanaan dan Desain Sistem Pembelajaran. Jakarta: Kencana.

sisdiknas. (2003). Undang-undang Republik Indonesia Tentang Sistem Pendidikan Nasional. Jakarta: Pemerintah Indonesia.

Sugiyono. (2013). Metode Penelitian Kuantitatif, Kualitatif, dan R\&D. Bandung: Alfabeta.

Susanto, A. (2013). Teori Belajar \& Pembelajaran di Sekolah Dasar. Jakarta : Kencana Prenada Media Group. 